\title{
8. Prisons and HIV in Papua New Guinea
}

\author{
GREG LAW AND SINCLAIR DINNEN
}

\section{The Prison System}

\section{Sinclair Dinnen}

The modern prison system in PNG has a relatively short history. For much of the colonial period the imprisonment of offenders, usually for short periods, was administered as an integral part of the larger system of 'native administration'. Prisons were viewed by colonial officials as educational institutions in which prisoners learned about the ways of the Europeans and acquired respect for the authority of the colonial government. 'Education' consisted primarily of physical labour and prisoners were utilised in a range of public works from grass-cutting to road construction. Every government station had its own gaol under the control of the resident magistrate who served simultaneously as judge, jury, prosecutor and jailer. The first prisons provided important sources of recruitment for some of the early members of the 'native constabulary', as well as offering other Papua New Guineans employment in some of the only minor positions in the colonial government that were then open to indigenes (Reed 2003, 29-42).

The current prison system has its origins in the process of institutional modernisation that commenced in the late 1950s (Sikani 1994; Reed 2003, 42-48). This involved the gradual dismantling of the old administrative model of colonial control and its replacement with the institutional framework of a modern justice system in anticipation of eventual independence and statehood. The first stage of this process was completed in 1957 with the establishment of a separate prisons branch under the Corrective Institutions Ordinance.

Responsibility for the administration of Papua New Guinea's prison system now lies with the PNG Correctional Service (CS) which was established as a state service and disciplined force under the Constitution. The mission of the CS is to enhance the safety of the community by providing secure and humane containment and rehabilitating detainees. For many years, the CS was the most 
neglected of PNG's law and justice agencies. Unlike the police and courts, CS institutions tend to be located away from urban centres and, hence, from public view. The larger institutions have been described as 'green prisons', beginning as prison farms with large open spaces and barrack-type accommodation surrounded by high security fences.

Providing secure containment has been a major and growing challenge in the post-independence period with regular prison breakouts - often en masse. For example, around 60 inmates were reported to have escaped from Bomana prison in September 2009. According to an unnamed CS source, the escape occurred because of a shortage of warders who did not turn up to work due to a pay dispute (Anon 2009a). A month later, newspapers reported that almost 500 inmates who claimed that they had not been fed for two days scaled the fourmetre fence enclosing Buimo prison but were quickly prevented from escaping by armed wardens (Anon. 2009b). After a daring breakout in January 2010 from Bomana prison, the Prime Minister dismissed the Minister for Correctional Services and suspended the Correctional Services Commissioner (Mercer 2010). Many mass escapes appear to have the tacit approval of prison staff and are often linked to industrial disputes between wardens and CS headquarters. These breakouts contribute, in turn, to localised 'crime waves' in the nearest town. Lack of adequate government support, overcrowded, outdated and poorly maintained facilities and sub-standard staff accommodation have contributed to low morale on the part of CS personnel. Approximately one-third of the prison population - rising to 50 percent in some institutions - consists of remandees awaiting trial. Some wait for periods of two years and upwards before their cases are heard. Delays in court proceedings have added greatly to internal pressures within the prison system. While correctional services have received significant levels of Australian aid (Moraitis 2008), many institutions continue to experience great difficulties in feeding, clothing and accommodating growing numbers of inmates.

Unsanitary conditions in some facilities threaten the health of staff, their families and detainees. Several facilities, including staff accommodation, have been condemned by health authorities as 'unfit for human habitation'. Similar conditions are found in police cells which are often used to hold inmates when space in CS facilities is unavailable. In September 2009, a detainee at Lae Central police station was suspected of having cholera, causing panic among the other 78 detainees and later the wider community when he escaped from hospital. Inspection of the police cells revealed blocked and overflowing ablution facilities, a condition shared among many police and prison cells (Anon 2009c). Prisoners in high-risk detention at Buimo prison in Lae told reporters that they had not 
had a proper shower for the previous three years (Korugl 2008). A number of deaths due to outbreaks of contagious diseases in prisons have recently been reported, but these problems are not new (Siaguru 2001, 208).

Convicted inmates and remandees have not always been separated in practice and resource shortages have also impacted on the capacity of the CS to provide separate facilities for juvenile inmates as required by law. Despite the 'correctional' tag and the commitment of many within the service to the ideal of rehabilitation, the rehabilitation of detainees remains undeveloped in many facilities and heavily reliant on church initiatives (Dinnen 2001, 52; Reed 2003, 52). Legal provisions also place constraints on the use of prison labour. Some prisons, like Port Moresby's Bomana prison, have active gang sub-cultures and, as with prisons elsewhere, significant numbers of inmates are released from PNG's prisons with a heightened commitment to criminal and anti-social activity (Dinnen 2001, 107; Reed 2003, 125-128; Goddard 2005, 101-105). Escapes and links between inmates and outside criminal activities have been attributed to prisoners' growing use of mobile phones. In February 2009, the Commissioner for Correctional Services banned visitors from carrying mobile phones following fears that a recent upsurge in armed holdups was being orchestrated from within prisons (Anon. 2009d).

There are currently 20 gazetted correctional institutions in PNG. These include Bomana (National Capital District), Buimo (Lae), Baisu (Mount Hagen), Kerevat (East New Britain), Kavieng, Manus (Lorengau), Lakiemata (Kimbe), Daru (Daru), Giligilii (Alotau), Biru (Popondetta), Beon (Madang), Boram (Wewak), Vanimo (Vanimo), Bundaira (Kainantu), Bihute (Goroka), Barawagi (Kundiawa), and BuiIebi (Mendi). The size of individual facilities and number of detainees varies considerably. At one end of the scale, Buimo has over 800 detainees, closely followed by Bomana. At the other end, Manus has about 40 detainees. Beon, just outside of Madang, is one of the larger facilities with a detainee population of around 350 in 2002. It has recently been upgraded as part of Australia's aid program (Moraitis 2008). There are also a number of smaller rural lockups that are administered jointly with the Department of Provincial and Local Level Government. The overall detainee population in 2002 was around 3200-3500 with around 92 percent of detainees being adult males, 4 percent females, and 4 percent being male juveniles. Data on the CS is difficult to obtain but some are available on the PNG government Law and Justice Sector Website: http://www. lawandjustice.gov.pg/www/html/7-home-page.asp.

Correctional Services has developed an HIV/AIDS and Other Infectious Diseases Strategy and introduced HIV awareness-raising programs among staff and detainees (see Patrick this volume). The first HIV behavioural study among prison inmates was conducted at the Bomana facility in 2005 (Pantumari et al. 2005) and prisons have been identified as high-risk settings that should 
be prioritised for the national response (NHASP 2006, 24-25). Among recent reported initiatives was a proposed pilot project at Buimo Prison to employ low-risk prisoners packing the new Seif Raida condoms, which was described as an opportunity to both rehabilitate prisoners and educate them about HIV while serving the national HIV response (Rai 2008). These and other initiatives for improving prison infrastructure, management and the welfare of inmates contend, however, with persisting funding and other difficulties. In January 2010, Prime Minister Somare personally took charge of the prison system, which he described as 'in crisis' (quoted by Mercer 2010).

\section{Prisons}

\section{Greg Law}

Prisons around the world are potentially among the unhealthiest places in our societies. They are places where peoples of varying ages and from different populations and backgrounds are compulsorily mixed, deprived of their freedom and are often exposed to direct threats of violence (including sexual violence) and infectious disease transmission.

The WHO publication, HIV in Prisons, notes that incarcerating people in prisons and denying them their freedom is supposed to be their punishment: exposing them to diseases which are often fatal is not part of their sentence and is unacceptable' (Bollini 2001, i). The US Bureau of Justice Statistics acknowledges that many researchers believe the number of prisoners with HIV is far higher than those officially documented (Clemetson 2004).

There are numerous risk factors for infectious disease transmission in prisons and police lock-ups in Papua New Guinea, including the usual scenario of intense overcrowding in the cell blocks (for both remandees and for those convicted and serving sentences). Overcrowded ablution blocks are another problem. With insufficient funds for maintenance, the septic systems do not cope with the load of excrement deposited in them and as a consequence, overflow into or in close proximity to the prison yard. Toilet blocks themselves are frequently awash with a mixture of urine and leaking water from damaged toilet pedestals and faulty plumbing. The potential for the transmission of infections such as typhoid, dysentery, hepatitis and tuberculosis in the prisons and police lockups is enormous and has been amply demonstrated in recent times (see, e.g., Korugl 2008).

Under the Correctional Services (CS) regulations every person admitted to a prison in PNG is required to have a medical examination to assess their physical fitness to serve the sentence they have been given. The examination is also to 
determine the presence of any infectious condition and enable management of that condition, to both cure the individual and to prevent the transmission of the infection in the prison setting. This examination is to be repeated on release from the corrective institution.

For three years in the early 1980s and another three years in the early 1990s, while the author was working in Madang, he acted as the visiting medical officer to Beon Prison just outside Madang town. This involved a half-day visit each week. All inmates admitted in the previous week and all to be released before the next week were given a limited medical examination and treatment was provided for any medical conditions found. During the first few visits numerous inmates were found to have STIs and these were treated. Included in this group were people who had been incarcerated for long periods of time yet who had acute STIs, indicating recent infection transmission within the prison setting. Once the medical visits became established, and included basic STI checks on admission to the facility, infections were identified on admission and treated. Following the instigation of this procedure, the numbers of new infections occurring within the prison dropped dramatically.

Beon Gaol is the only PNG prison where these medical checks have taken place in recorded history and since the mid-1990s have not happened there either. An audit of PNG's prisons conducted in 2008 called for the employment of more health and welfare professionals in CS institutions owing the the deaths of prisoners from outbreaks of contagious disease in recent years (Anon. 2008a).

The CS has provision in the records for each inmate for the recording of the medical examination of prisoners on admission and release but these examinations are not carried out due to the lack of trained medical staff. Each prison has a small aid post staffed by a Community Health Worker or Orderly, who provides basic medical attention for the inmates of the facility and the CS staff and families. The difficulty in getting the medical examinations performed routinely is in identifying medical staff from provincial health facilities who are (a) interested in prison health and (b) able to take enough time from their already heavy work loads to undertake prison health work on a regular basis.

Apart from the infectious diseases already mentioned, as in prisons all over the world, there is also great potential for the transmission of sexually transmitted infections (STIs) including the Human Immunodeficiency Virus (HIV). In prisons in PNG, the main types of behaviour that greatly increase the risk of STI/HIV transmission include:

- Tattooing with shared implements

- Skin cutting with shared implements

- Unprotected sexual intercourse. 
We will look at each of these three groups of risky behaviour in turn. Injecting drug use, which is a major factor in the high prevalence of HIV among prison populations in many countries, is fortunately so far not a factor in PNG (Dolan et al. 2007)

\section{Tattooing}

It is common practice in PNG for prison inmates (especially sentenced prisoners but also remandees) to tattoo themselves and their fellow inmates. Tattoos vary in design but frequently there are recurring designs that are easily recognised by initiates for purposes of peer recognition in the community after release (see also Reed 2003 ). The common method of tattooing in prisons is to use either a razor to cut into the skin, or needles or thorns to make multiple stab wounds. After these lesions are made in the desired pattern, soot, usually from the base of the large cauldrons used for cooking over open fires, is rubbed into the wounds. Due to obvious lack of resources in the prison setting, it is common for inmates to share the cutting or piercing instruments. If any cleansing is done at all between uses, it usually consists of simply washing in tap water, but the more common scenario is to wipe the implement on cloth or clothing between uses. This practice clearly holds potential for the transmission of numerous blood borne infections including HIV, Hepatitis B and C and possibly syphilis.

\section{Skin-cutting}

Incising of the skin by inmates (either to themselves or to their fellows), is common in PNG prisons and is practised for several reasons. The principal two of these is either for decorative scarification or more commonly for penile modification. Decorative scarification may be anywhere on the trunk or limbs but is more commonly performed on the chest and consists of horizontal lines incised over the mid-chest at about the junction of the upper and middle thirds of the sternum. In some provinces pseudo-traditional scarification in the back, chest, buttocks and thighs may also be conducted in the prison setting, however these are rare as the practice is more easily noticed by CS staff and thus punishable.

Penile modification is traditional in some areas of PNG. For example, it is fairly common to perform circumcision on male babies and very young boys in parts of West New Britain. Likewise, dorsal slit of the prepuce is performed during initiation of adolescent males in the Rai Coast area of Madang Province. Over the past 20 years or so, techniques of modification of the dorsal slit, including insertion of foreign bodies between the layers of the slit prepuce and other 
skin of the penis, have been introduced, initially by Asians, especially those involved in the logging and timber industry. Anecdotal evidence suggests that these workers introduced the practice to local men in the areas in which they worked.

The practice of penile modification is common throughout prisons in PNG, as it is in some general communities, and is believed to be increasing (cf. Reed 2003,113-116; NACS 2006, 38). In prison, where communal bathing is the rule, male inmates who have not had some form of penile modification are often ridiculed, and submission to the practice by those prisoners (especially younger men) who have not previously undergone the procedure is often a rite towards being fully accepted into the 'community'. There are as many variations in reasons for undergoing the procedure as there are in the techniques of the actual procedure.

As mentioned already, one reason for submitting to penile modification procedures is the felt need for compliance with the sub-culture of the prison community. A further reason given for undergoing the procedure is the widely held belief that the dorsal slit of the prepuce and the resultant 'clean head' of the glans penis provides protection against STIs generally (cf. NACS 2006, 38). Others believe that the resultant scarring from the dorsal slit causes enlargement of the girth of the penis. The insertion of foreign bodies into the prepuce between the layers of the prepuce at the time of the incision and/or the insertion of foreign bodies below the skin of other parts of the penis is performed for the same reason. It is widely believed that the resultant bulges and general increase in the girth of the penis will greatly enhance sexual pleasure for the female partner during coital thrusting, so that she will always be 'coming back for more'.

The author has frequently been called upon to later surgically remove these foreign bodies and the resultant fibrotic tissue due to either recurrent infection or discomfort. Items inserted below the skin of the penis include steel ball bearings, glass marbles, plastic buttons, pieces of rounded carved wood, lids of tooth paste tubes, tooth paste itself (squeezed into the incisions and later hardening), rounded pieces of glass (often from the handle of brown glass coffee jars) and small key rings. In the prison setting, the most common material inserted into the penis is a part of the handle end (although the bristle end has also been used) of a plastic tooth brush. A piece about $1-2 \mathrm{~cm}$ long is broken off and rubbed against cement floors or walls until the edges and corners are smooth. This is then inserted through an incision either into the prepuce or other part of the penile skin.

In most cases incisions made by inmates in PNG prisons are made with razor blades. Since it is mandatory for all sentenced prisoners to shave daily, razor 
blades are available. However due to the rationing of these items, razors used in 'surgical' procedures are often shared and, again, if any cleansing is done between use on different people, it will usually only involve rinsing under tap water. Given the depth to which these incisions are made, should any antecedent 'patient' be HIV positive, the potential for HIV (and Hepatitis B and C) transmission in this scenario is high.

\section{Sexual Transmission}

Thus far we have looked at the potential for the percutaneous transmission of HIV in PNG prisons. Probably the greatest risks for transmission of HIV and other STIs exist in unprotected sexual intercourse. As in prisons around the world sexual intercourse occurs in prisons in PNG (see also Reed 2003, 116119). At any one time the prison population in PNG is around 3,000 males and from 100-300 females (Karela, n.d.). In the case of the male prison population, both anal and oral sexual intercourse occurs. This may involve just two partners but may also involve group participation. As is the case internationally, men who do not identify as homosexual and who may not indulge in homosexual activities when outside the prison, do so when confined for periods of time away from their female partners. The reasons given by inmates for involvement in male homosexual activities whilst in prisons vary. In some cases it is voluntary and consensual, either from the natural inclination of the partners or as an acceptable substitute for their usual heterosexual activities. In others it may occur under coercion - either in exchange for protection from others, or for extra food or other items smuggled into the prison (often tobacco), or for the security of having a guardian. In these cases it is usual that the receptive (and rewarded) partner is a youth or at least considerably younger and thus more susceptible to abuse, than the other partner. Sometimes the sexually receptive partner may have been seen having sex with another inmate and is then coerced by threats of reporting to prison authorities to provide the same sexual service for other inmates.

The more traumatic of the 'sexual liaisons' that occur in the prisons is that of sexual assault (see, e.g. Kelola 2009). This sometimes happens when a younger male inmate is approached for sexual favours and may even be offered rewards but refuses to comply. It may also happen when the 'receptive' partner is caught by other inmates indulging in sexual activities with another prisoner, or is rumoured to have been involved and then refuses the approaches of other inmates. These attacks again may be by an individual prisoner, or may involve multiple assailants. In a recently reported case, prisoners retaliated against two fellow inmates who were serial rapists (Kelola 2009). Serious anal trauma is often the result of these sexual assaults. Whilst any form of unprotected sexual 
intercourse with an infected person is a risk of HIV and other STI transmission, it is well documented that unprotected anal intercourse, and especially as the result of sexual assault, constitutes the highest risk.

In PNG, sexual liaison involving female prisoners is less well documented. Certainly there are recorded cases of female detainees being involved in sexual activity (either consensually or allegedly forced) whilst in custody in lockups or other institutions (but see Reed 2003, 120-121). The author has also been consulted to extract from the vagina of female prisoners, pieces broken off from dildos made of available material. This matter has included pieces from 'carved' peeled raw sweet potato and other vegetable matter and also pieces broken from the deep fried wholemeal 'cakes' prepared for prisoner's breakfasts. It is highly unlikely though that these devices are shared and thus would not be seen as 'vectors' for the transmission of HIV or other STIs.

\section{Summary}

In summary then the most high-risk behaviour leading to the potential transmission of HIV (and other STIs) in the prison setting in PNG, includes skin-cutting or piercing with shared instruments and unprotected sexual intercourse. It is the oft-reiterated policy of the CS that condoms are not and will not be made available to inmates of corrective institutions. We have here a 'Catch 22' situation. The CS regulations that prevent the issuing of condoms to prisoners is based on the fact that the law in PNG makes sodomy and 'unnatural sexual acts' criminal offences, thus to issue condoms in single sex prisons is viewed as tacitly condoning those acts. Yet the HIV/AIDS Management and Prevention Act of 2003 (see Stewart this volume) clearly states that to deprive anyone of the means of protecting themselves against HIV is also an offence under that Act. Urgent discussion needs to take place at a national level to solve this seeming impasse.

Supervision of prisoners is clearly a major problem. Due to staffing shortages and inadequate ratios of CS officers to inmates in corrective institutions, it is obvious that close supervision of prisoners is not possible. On weekends especially, inmates are confined to the prison cell blocks and yards with minimal close supervision, which allows for hidden 'surgical' procedures to be performed with relative ease. Similarly after the evening meal, prisoners are locked up inside large open dormitory blocks each housing scores of inmates and there is usually no inspection or supervision until the doors are unlocked the following morning. It is unlikely that these conditions will change unless adequate funding is allocated to the CS to allow the raising of staffing ceilings and increased training of officers. 
It is also imperative that younger prisoners be kept in separate accommodation from the other inmates to decrease the potential for sexual assault. Some inroads have been made to achieve this in the larger prisons, with the provision of separate juvenile blocks but a lot more needs to be done to expand existing facilities and to ensure that each prison has separate juvenile accommodation blocks.

Provision also needs to be made for the basic health checks to be carried out on each inmate on admission and prior to release from the corrective institutions. This may be possible by negotiation and collaboration with provincial health authorities and hospitals but it would also be helpful for CS to look at the possibility of recruiting trained medical staff at least on a regional basis to regularly visit Corrective Institutions in order to carry out routine and regular health checks on inmates.

At this stage voluntary counselling and testing (VCT) for HIV in prisons in PNG is limited. The lack of facilities and shortage of resources within prisons has curtailed the implementation of HIV prevention measures beyond awarenessraising (NHASP 2006, 25-26). Yet in response to education campaigns, prisoners have made regular requests in numerous prisons around the country for HIV testing. As the VCT programme is rolled out nationally, it is imperative that counsellors be trained to extend this service to the inmates of prisons as well as the general population. As the planned availability of HIV rapid test kits increases, the possibility of providing a VCT service to inmates of prisons in PNG will become more viable. As prisoners become aware of their HIV status, measures for the maintenance of confidentiality, easier access to health services and the supply of condoms will achieve even greater importance.

\section{References}

Anon. 2009a. The National, 28 September 2009.

Anon. 2009b. The National, 21 October 2009.

Anon 2009c. The National, 24 September 2009.

Anon 2009d. Post-Courier, 10 February 2009.

Bollini P., ed. 2001. HIV in Prisons: A Reader with Particular Relevance to the Newly Independent States. Copenhagen: WHO Regional Office for Europe.

Rai, Frank. 2008. Casual Jobs for Prisoners. Post-Courier, 31 July 2008.

Clemetson L. 2004. Links Between Prison and AIDS Affecting Blacks Inside and Out. New York Times, 6 August. 
Dinnen, Sinclair. 2001. Law and Order in a Weak State: Crime and Politics in Papua New Guinea. Adelaide and Honolulu: Crawford House and Hawaii University Press.

Dolan, Kate, Ben Kite, Emma Black, Carmen Aceijas, Gerry V. Stimson. 2007. HIV in Prison in Low-Income and Middle-Income Countries. Lancet Infectious Diseases 7 (1): 32-41.

Goddard, Michael. 2005. The Unseen City: Anthropological Perspectives on Port Moresby, Papua New Guinea. Canberra: Pandanus Books.

Karela, K., Deputy Police Commissioner, PNG, personal communication.

Kelola, Todagia. 2009. Notorious Pair Beaten up over Sodomy Claim. PostCourier, 20 February 2009.

Korugl, Peter. 2008. Buimo Inmates in 'Hell'. Post-Courier, 4 December 2009.

Mercer, Phil. 2010. Papua New Guinea's Correctional Services Minister has been Sacked following a Brazen Jailbreak. BBC News, Sydney, 21 January 2010.

Moraitis, Chris. 2008. Speech for the Official Opening of New Facilities at Beon Prison, 8th July 2008. http://www.png.embassy.gov.au/pmsb/Speech080708. html (accessed 27 April 2010).

NACS (National AIDS Council Secretariat). 2006. HIV/AIDS Behavioural Surveillance Survey within High Risk Settings. BSS Round 1. [Boroko]: National AIDS Council Secretariat.

NHASP (National HIV/AIDS Support Project). 2006. High Risk Settings Strategy Report: Moving beyond Awareness. Milestone 90.

Pantumari, Joachim, John Millan, Emil Ngansia, Joe Bunefa. 2005. Human Immunodeficiency Virus Behavioural Study among Inmates, Bomana Prison, Port Moresby, Papua New Guinea. Boroka: PNG National AIDS Council, supported by AusAID.

Reed, Adam. 2003. Papua New Guinea's Last Place: Experiences of Constraint in a Postcolonial Prison. New York: Berghahn Books.

Siaguru, Anthony. 2001. Prison Welfare in More Ways than One. In In-House in Papua New Guinea with Anthony Siaguru, by Anthony Siaguru, 207-209. Canberra: Asia Pacific Press.

Sikani, Richard. 1994. The Establishment of the Corrective Institution Branch and the Australian Colonial Detainee Rehabilitation Policies in TPNG Gaols, 1950-1975. NRI Discussion Paper no. 75. Boroko: National Research Institute. 